\title{
Literature Critique: "Competition Law, Enforcement and the Australian small business sector"
}

\author{
Munshi Samaduzzaman \\ Adjunct lecturer, University of Liberal Arts Bangladesh, Dhaka, Bangladesh
}

\begin{abstract}
Various developed nations nowadays have put all their efforts to regulate competition laws for international market. And, Australia is not an exception to this implementation; the further growth and development of the Australian industries are mainly regulated by the Australian government in order to oversee if the organizations, business owners, employees are in full compliance with the Completion law that enforces several business laws that govern many small and medium enterprises on operating and entering into complete competition both in an open market operation.
\end{abstract}

\section{Introduction}

This paper aims to evaluate critically the Journal Article literature written by Schaper, 2010 (pp. 7 - 18) entitled "Competition Law, Enforcement and the Australian Small Business Sector" that is very relevant to the issues and challenges that Australian SME (Small and Medium sized Enterprises) sector is experiencing nowadays in entering the international market. The situation of the Australian SMEs is further analyzed through giving an overview on the topic, and more importantly is identifying the research question and its corresponding research objectives of the study. The support of theoretical framework is essential in order for this critical analysis to narrow down to the main substance of the issue. Hence, the utilization of relevant literatures is necessary in order to discuss the basis of the research objectives, theories, and methodologies that are applied in the study, as well as the manner they are being used in the topic. Furthermore, at the latter part of this paper, a conclusion is provided in order to give stress to the focal points and significant implications of the critique.

\section{Summary of the Article}

Schaper, (2010) has discussed in his article entitled "Completion law, Enforcement and the Australian Small Business Sector" the issues and challenges in the implementation of the Competition Laws in the Australian open market. Though, these regulations mainly control and manage the small and medium enterprises through the Competition \& Consumer Act 2010 which formerly known as the Trade Practices Act 1974; this Act was especially designed for the small and medium businesses to address various issues and challenges pertaining to provision of collective bargaining arrangements, exclusion of unscrupulous acts among business owners, and implementation of right business ethics that must be practiced within the SME organization and in the competitive environment.

\section{Research Question}

The enforcement of competition laws among small and medium industries in the country caused various issues and challenges that include the very low level of awareness about international competition among SME's. This is the very reason that it has been hard to detect if there is any violation and noncompliance of competition laws among these small and medium companies. Aside from that, it is also harder to develop effective international and advanced business education and outreach strategies for the SME sector because it is kind of difficult to rely on their self-regulation approach in assessing if these SMEs are in compliance with the competition law or not. Another important factor to consider is the law regulators should also take into account the proportionality of fines and penalties that they impose on SME sector if these companies break the regulations. (Schaper, 2010, pp. 10-12) Hence, this paper would like to find out what is the major role of "Competition law, enforcement and the Australian SME Sector" in the advancement and globalization process of the small and medium business sector in the country?

\section{Theoretical Framework}

Golodner 2001 has stated that "The limited academic debate to date within the small business research community on competition policy appears to strongly support the notion that fair and open competition is central to entrepreneurship and small business development." (Cited in Schaper, 2010, pp. 8 -9).

According to Audretsch, 2004; Audretsch, van Leeuween, Menkveld and Thurik, 2001; competition, generally, allows new, small and self-motivated companies to enter an international markets, as well as it introduces new innovations to customers, to provide greater opportunities to buyers, and - if the sellers 
provide the right type of product or service at the right price - it can enable them to flourish in the business. (Cited in Schaper, 2010, pp. 8 -9).

These theoretical frameworks fit to the development and success of the small and medium business sectors. Indeed, the innovative strategies, the removal of international trade and investment barriers, privatization, as well as the deregularization of trade and investment policies provide great international opportunities and profitability to SME sector.

\section{Literature Review}

It is obvious that large companies have more market opportunities as to compare to the SME firms. On the contrary, these small and medium companies have limited economic resources, as well as restricted access of information on the legal and economic matters that can possibly help them to grow and develop as organizations. But, since they only have inadequate information and access to suppliers and consumers, they are not given a chance to prove themselves in the international competition.

Chaffetz (1953) says that study of the relationship between small/medium enterprises and the different areas of the competition law policy has been limited and scattered.

In the same way, there are several questions nowadays on the effectiveness of the competition laws which need to have further research and examination on every essential detail that includes the level of knowledge of SME business owners have about the antitrust and competition policies. These are the barriers for the small business owners to comply with the legal remedies (Ncube \& Paremoer, 2009) was cited in the Schaper, 2010 - which suggests that new and small companies are more likely to seek legal remedies when a competitor breaks the antitrust or trade practices regulations. Again, further research is still required to do in order to determine if what are the factors (cartels, collusion, or cartel behavior) that would prevent SMEs from seeking legal remedy. In this relation, cartels and some other illegal arrangements for "fixing the market" business are considered serious breaches of the Competition Act that leads to criminal liabilities in other countries.

\section{Problem Formulation}

This article has addressed the various issues and challenges that make small and medium enterprises (SMEs) tremendously different from the large companies' operation in the competitive environment. As a matter of fact, there are 90 percent of small-size business entities that do trading in the developed countries. While in Australia, it is more than 96 percent of them comprised the Australian market. (Schaper, 2010, pp. 8-9)

Despite of this, it is still ironic that they still have difficulties in competing in open markets. Additionally, it is more likely obvious that the responses to competition laws are very limited from the side of SMEs. So, how does competition law help the SME sector to become aggressively competitive in the world market?

\section{Research Objective}

The basis of the research objective of this article is the tremendous impact of the proper implementation of Australian competition laws among small and medium-sized companies in ensuring equal and open marketplace opportunities for different SME industries. In this paper, the researcher has shown the angle that the Australian government has come up with the laws and frameworks that would help all large, medium or small industries to be treated fairly. However, this critique also represents the basis on how Australian policy makers would ensure to the SME sector that these competition laws and theoretical and legal models would be effective tools in promoting full competition and globalization among SME sector. Actually, this has been challenge for the competition law legislators and enforcers in how to fully make a change in the SME sector towards in an advanced and globalized business setting.

\section{Research Methodology Used}

Table 3 (Schaper, 2010, p.16), COUNT OF PRIVATE SECTOR FIRMS IN AUSTRALIA, 1995-2007 has revealed the sources from Australian Bureau of Statistics' survey which conducted in 2007 that the level of awareness and knowledge of SMEs on the competition laws and its significant impacts on the continuous growth of the SME sector are strictly determined. This quantitative research's cited by Schaper (2010) in his research determines how many number of small and medium-sized companies in Australia that complied with the substantial changes made in 1995 in the pursuant of the Trade Practices Act and national competition policy which, fortunately, improve their business condition and profitability. Schaper (2010, pp. 15 - 16). Aside from that, a descriptive approach has also applied in the article through a larger collection of the bodies of relevant literature that obviously helped to provide strong foundation on the paper's structure. 


\section{Significance and Limitations}

There is still further need for large-scale research that may focus on the practical answers on how the SMEs would finally fully appreciate and comply voluntarily with the Australian competition laws. Correspondingly, it would be a wide-research that would address every concern and issue of the SME parties that involved in the competition regulations enforcement in the SME sector. In view thereof, it is very important to discuss the major role that supposedly the Competition law of Australia would play in the SME sector. It seems that, before it can be conform, there must be first a massive body of data and information and a longitudinal research that helps the policy makers, regulators to have better understanding on whatever issues need to be addressed, instead of making prior hypothesis.

\section{Conclusion}

SMEs like any other business; they have also different nature of business from one another. And, it is a fact that SME sector is not as aggressive and innovative as to compare to large and modern industries. Therefore, it is highly recommended that the Australian completion legislators and regulators must be sensitive enough to understand what these companies do come from, their sentiments, needs and concerns. If the policy legislators and regulators are sincere enough with their advocacy to help these SME companies to become world-class entrepreneur, this paper suggests that they must be given enough place in the world market as well a adequate capital flow by reputable financial institutions.

\section{References}

[1] Schaper, Michael T. Competition Law, Enforcement and the Australian Small Business Sector [online]. Small Enterprise Research: The Journal of SEAANZ, Vol. 17, No. 1, 2009 - 2010: 7-18. Availability :< http://search.informit.com.au/documentSummary;dn=010709253897351;res=IELBUS> ISSN: 1321-5906. [Cited 5th Jun 12].

[2] Golodner, A.M. (2001) Antitrust, innovation, entrepreneurship and small business Small Business Economics 16(1): 31-35.

[3] Audretsch, D.B.(2004) Small firms, innovation and competition, in: Neumann, M. \& Weigand, J. (eds.) International handbook of competition, pp.88-114, Cheltenham: Edward Elgar.

[4] Chaffetz, H.E. (1953) the antitrust laws and small business Antitrust Law Journal No.2, pp.77 ff. Competition \& Consumer Act, 2010 (Cth)

[5] Ncube, P. and Paremoer, T. (2009) Competition policy in South Africa and small business: a review of enforcement cases Paper presented to the $3^{\text {rd }}$ annual Competition Conference, Competition Commission of South Africa. 